\title{
Microwave-assisted synthesis of thermo- and pH-responsive antitumor drug carrier through reversible addition-fragmentation chain transfer polymerization
}

\author{
Y. M. Wang ${ }^{1}$, S. X. Zheng ${ }^{1}$, H. I. Chang ${ }^{2}$, H. Y. Tsai ${ }^{2}$, M. Liang ${ }^{*}$ \\ ${ }^{1}$ Department of Applied Chemistry, National Chiayi University, 60004 Chiayi, Taiwan, ROC \\ ${ }^{2}$ Department of Biochemical Science and Technology, National Chiayi University, 60004 Chiayi, Taiwan, ROC
}

Received 14 September 2016; accepted in revised form 6 December 2016

\begin{abstract}
This paper reports the rapid synthesis of a dual-responsive copolymer through reversible addition-fragmentation chain transfer (RAFT) polymerization under microwave irradiation. Through use of 2-ethoxycarbonothioylthio acetic acid (ECTA) as a RAFT agent, the microwave-assisted polymerization rate of $N$-isopropylacrylamide (NIPAM) was approximately 150 times faster than that observed under conventional heating conditions, and the resulting homopolymer can be reactivated as a macroinitiator to produce poly( $N$-isopropylacrylamide-block-methacrylic acid) (PNIPAM- $b$-PMAA) block copolymers through a similar method. Research into the detailed polymerization kinetics of the PNIPAM and PNIPAM- $b$-PMAA revealed living characteristics that included a linear relationship between $M_{\mathrm{n}}$ and conversion, controlled molecular weights, and a relatively narrow molecular weight distribution. The solution of the block copolymers in phosphate-buffered saline buffer displayed a phase transition at a lower critical solution temperature transition of $42^{\circ} \mathrm{C}$, and altering the $\mathrm{pH}$ from 7 to 3.5 resulted in various degrees of polymer aggregation in the solution. Cisplatin was loaded to the polymeric carrier through a ligand exchange to form a macromolecular prodrug. The observed critical micelle concentration was $0.25 \mathrm{mg} / \mathrm{mL}$. Overall, these polymers offer considerable potential for developing a new multifunctional drug delivery system.
\end{abstract}

Keywords: smart polymers, microwave-assisted synthesis, reversible addition fragmentation chain transfer polymerization, polymer drug conjugate, anticancer drug

\section{Introduction}

Reversible addition-fragmentation chain transfer (RAFT) polymerization has been extensively used to prepare polymers with desired molecular weights, a narrow molecular weight distributions, and well-defined nanostructures. A remarkable feature of RAFT is its general versatility with respect to monomer choice, which can be used to build various amphiphilic nanostructures such as micelles, vesicles, and nanoparticles with potential (bio)pharmaceutical applications $[1,2]$. In the design of 'smart' polymers based on RAFT techniques, the well-controlled structures of these systems offer numerous advantages compared with free radical systems such as more uniform response behavior, controlled size, and molecular weight. A wide range of RAFT-derived polymers has now been explored for applications in optoelectronics, drug delivery vehicles, and star polymer rheology control agents [3]. Nevertheless, the relatively low polymerization rates as well as heterogeneity of the by-products render its biomedical application difficult, and the often high reaction temperatures and extended polymerization times can be problematic for achieving a consistent polymer composition. Therefore, it is of great interest to develop novel methods that can prepare stimuli-responsive

\footnotetext{
${ }^{*}$ Corresponding author, e-mail: mliang@mail.ncyu.edu.tw (C) BME-PT
} 
polymeric nanoparticles with high polymerization rates, while simultaneously maintaining reasonable molecular weight control and livingness of nature for biomedical applications.

Microwave irradiation appears to be an attractive synthetic tool for solving these drawbacks because of several advantages such as reduced reaction times, increased product yields, limited generation of byproducts, and environmentally benign preparation. Microwave-assisted organic synthesis has been widely applied in the medicinal chemistry over the last decade [4]. For example, Imatinib (Gleevec), a marketed anticancer drug, can be produced through microwave heating in five steps with shorter reaction times and higher yields than what can be obtained through traditional heating methods [5]. Various inhibitors and pharmaceutical molecules have been synthesized through microwave-assisted synthetic protocols to treat infectious diseases such as tuberculosis, HIV/AIDS, malaria, and hepatitis C [6-9]. Other notable examples, including biologically active heterocycles for Sildenafil analogs $[10,11]$, nontoxic biofilm inhibitors (antimicrobial derivatives) $[12,13]$, sirtuin 2-selective inhibitors [14, 15], crosscoupling reactions $[16,17]$, and positron emission tomography $[18,19]$, have also been reported, and some reactions have been evaluated in a scale-up fashion $[20,21]$. In contrast to these small molecules, reports of polymer drugs or biomaterials synthesized under microwave conditions are comparatively limited [22-24]. In the field of polymer synthesis, microwave irradiation has been widely used in step-growth polymerizations [25], free radical and ring-opening polymerizations [26-27]. Studies concerning controlled-radical polymerizations such as atom transfer radical polymerization (ATRP) or nitroxide-mediated radical polymerization (NMP) under microwave conditions, however, are relatively sparse [28-31]. Recently, microwave-assisted RAFT polymerization has appeared in the literature [32], although only a few types of hydrophilic monomers, such as $N, N$-dimethylacrylamide, $N$-isopropylacrylamide [33, 34], $N$-(2-hydroxypropyl)methacrylamide [35], and diallyldimethylammonium chloride [36], have been examined for amphiphilic copolymer applications. In this paper, we report the first and fast microwave-assisted polymer-drug conjugate synthesis featuring both $\mathrm{pH}$ and temperature responsiveness through RAFT polymerization. The responsiveness and self-assembling behavior of these polymers were investigated, and the kinetic data for both PNIPAM and the subsequent chain extension to a diblock copolymer under microwave irradiation were determined.

\section{Experimental}

\subsection{Materials}

NIPAM (Tokyo Chemical Industry Co., Ltd., Japan) was recrystallized from mixtures of ethyl acetate and hexane ( $1 / 5$ by volume) and dried in a vacuum prior to use. Methacrylic acid (MAA, Showa, Tokyo, Japan) was purified through distillation and stored in $\mathrm{N}_{2}$ prior to use. 2,2-Azobis-isobutyronitrile (AIBN, Showa, Tokyo, Japan) was recrystallized in ethanol before use. Diethyl ether ( $>99.0 \%)$, toluene $(>99.0 \%)$ and methyl alcohol $(99.9 \%)$ were purchased from ECHO, Miaoli, Taiwan. Trimethylsilyldiazomethane (TMSD, 2M solution in hexanes) and cisplatin (99.99\%) were purchased from ACROS Organics, Belgium. Tris(hydroxymethyl)aminomethane (99.9\%) was purchased from MP Biomedicals, Ohio, USA. These reagents were used without further purification. 2-Ethoxycarbonothioylthio acetic acid (ECTA) was obtained through a reaction of 2-bromoacetic acid with potassium-o-ethyl dithiocarbonate, according to procedures outlined previously [37]. Mouse osteoblast-like cells (7F2), an osteoblastic cell line isolated from $\mathrm{p} 53-/-$ mice was obtained from the Bioresource Collection and Research Center (Hsinchu, Taiwan).

\subsection{Instrumentation and measurements}

${ }^{1} \mathrm{H}$ spectra were recorded using a $300 \mathrm{MHz}$ (VarianMercury ${ }^{+} 300$, Oxford, USA) spectrometer by employing a deuterated solvent. Fourier transform infrared (FTIR) spectra were measured using a Perkin Elmer spectrophotometer (Spectrum one, Oxford, UK). Gel permeation chromatography (GPC, Waters 1515, USA) were equipped with WATERS STYRAGEL HR4E DMF, HR4 DMF, HR1 DMF and a refractive index detector (Waters 2410). The molecular weights and dispersity $(\nexists)$ of the products were calibrated using poly(methyl methacrylate) molecular weight standards in the molecular weight range of 2,500-520000 g/mol (Polymer Standards Service, USA). GPC was performed using a dimethylformamide (DMF) eluent containing $0.05 \mathrm{~mol} / \mathrm{L}$ lithium bromide at $80^{\circ} \mathrm{C}$ with a flow rate of $0.8 \mathrm{~mL} / \mathrm{min}$. Prior to the GPC analysis, the polymers were modified by methylating the carboxylic acid 
groups with trimethylsilyldiazomethane in the DMF. Microwave-assisted polymerization was conducted inside a single-mode stainless steel cavity (CEM Discover S-Class NP-1008, USA) equipped with an infrared temperature sensor and simultaneous cooling system. The $\mathrm{pH}-$ and temperature-sensitive behaviors of the polymers were characterized by applying the UV2100+ spectrophotometer (Unico, New Jersey, USA) at $1-2 \mathrm{mg} / \mathrm{mL}$ at $600 \mathrm{~nm}$. The $\mathrm{pH}$ of the test solutions was controlled by adding tris(hydroxymethyl)aminomethane or phosphoric acid. Dynamic light scattering (Zetasizer Nano ZS90, Malvern, England) was used to confirm the particle size distribution of polymer drugs at $4 \mathrm{~mW} \mathrm{He}-\mathrm{Ne}$ laser. Transmission electron microscopy (TEM) images were made with a JEM-2100 (JEOL, USA) electron microscope operated at an acceleration voltage of $100 \mathrm{kV}$. Platinum contents were determined using an inductively coupled plasma mass spectrometry (ICPMS) instrument (Agilent 7500ce, Japan), and fluorescence measurements were performed on a HITACHI F-4500 FL spectrophotometer (Hitachi, Tokyo, Japan).

\subsection{Synthesis}

\subsubsection{Microwave RAFT polymerizations of NIPAM}

Poly( $N$-isopropylacrylamide) (PNIPAM) was prepared through RAFT polymerization by using 2,2azobis-isobutyronitrile (AIBN) as the primary radical source and ECTA as the chain transfer agent (CTA). A $20 \mathrm{~mL}$ glass tube equipped with a magnetic stirrer was loaded with NIPAM (1 $\mathrm{g}, 8.83 \mathrm{mmol})$, AIBN $\left(0.7 \mathrm{mg}, 4.26 \cdot 10^{-3} \mathrm{mmol}\right)$, and ECTA $(159 \mathrm{mg}$, $0.883 \mathrm{mmol})$. The tube was deoxygenated by evacuation and back-flushed with nitrogen three times. Next, $4 \mathrm{~mL}$ of toluene was added with a syringe, and the resulting solution was purged with nitrogen for $20 \mathrm{~min}$ and placed in the cavity of the microwave instrument. The temperature was programmed to $75^{\circ} \mathrm{C}$ at a maximum $100 \mathrm{~W}$ irradiation dose with cooling control. After $10 \mathrm{~min}$, the polymer was dissolved in acetone $(2 \mathrm{~mL})$ and re-precipitated in diethyl ether $(200 \mathrm{~mL})$. Subsequently, the polymer was filtered and dried in a vacuum $(0.71 \mathrm{~g}$, yield: $71 \%) .{ }^{1} \mathrm{H}$ NMR $\left(\mathrm{CDCl}_{3}\right) \delta: 1.13-1.33\left(\mathrm{CH}\left(\mathrm{CH}_{3}\right)_{2}\right.$ of NIPAM $), 1.51-$ 1.97 (the methylene protons of polymer backbone), 2.03-2.50 (the methine protons of the polymer backbone), $3.99\left(-\mathrm{NHCH}\left(\mathrm{CH}_{3}\right)_{2}\right.$ of NIPAM), and 4.62 $\left(-\mathrm{OCH}_{2} \mathrm{CH}_{3}\right.$ of ECTA); ${ }^{13} \mathrm{C}$ NMR $\delta: 13.9,22.6$,
32.2-38.1, 32.2, 41.2, 42.4, 70.6, and 174.3; and IR $(\mathrm{KBr}) \vee\left[\mathrm{cm}^{-1}\right]: 1172(\mathrm{C}-\mathrm{O}), 1574(\mathrm{~N}-\mathrm{H}), 1651$ $(\mathrm{C}=\mathrm{O}), 2951,2936(\mathrm{C}-\mathrm{H})$, and $3300(\mathrm{~N}-\mathrm{H})$. This polymer was used as the macro-CTA for subsequent copolymerization.

Kinetic studies were performed similarly, except that the samples were removed periodically by using a syringe during polymerization to determine the monomer conversion and molecular weight. To compare the results with those obtained using a conventional heating method, the reaction mixture with the same weight ratios and reaction conditions was performed in an oil bath.

\subsubsection{Microwave block copolymerization of PNIPAM with MAA}

The block copolymer PNIPAM- $b$-MAA was prepared in methanol using PNIPAM as the macro-CTA $\left(M_{\mathrm{n}}=\right.$ approximately $\left.6000 \mathrm{~g} / \mathrm{mol}, Ð=1.3\right)$ and AIBN as the primary radical source. First, a $20 \mathrm{~mL}$ glass tube equipped with a magnetic stirrer was loaded with PNIPAM (120 mg, $0.02 \mathrm{mmol}$ ), methacrylic acid (172 mg, $2 \mathrm{mmol})$, AIBN (0.2 mg, $1.22 \cdot 10^{-3} \mathrm{mmol}$ ), and DMF $(60 \mu \mathrm{L})$. The resulting solution was purged with nitrogen for $20 \mathrm{~min}$, and $5 \mathrm{~mL}$ of toluene was then added with a syringe. The tube was placed in the cavity of the microwave instrument, and the temperature was programmed to $75^{\circ} \mathrm{C}$ at a maximum $100 \mathrm{~W}$ irradiation dose with cooling control. After $10 \mathrm{~min}$, the polymer was dissolved in methanol $(2 \mathrm{~mL})$, precipitated in diethyl ether $(200 \mathrm{~mL})$ and collected as a white powder by filtration. The polymer was purified by dissolving it in a minimal amount of methanol and re-precipitated in a 10 -fold excess of an $\mathrm{Et}_{2} \mathrm{O}$ solution. Thereafter, the polymer was collected using filtration, washed with $\mathrm{Et}_{2} \mathrm{O}$, and dried in a vacuum overnight to provide $0.15 \mathrm{~g}$ of the polymer. The carboxylic acid content was subsequently determined by titration with $0.1 \mathrm{~N} \mathrm{NaOH} .{ }^{1} \mathrm{H}$ NMR $\left(\mathrm{CDCl}_{3}\right) \delta: 0.78-1.28$ (the methyl protons of the PMAA and $\mathrm{CH}\left(\mathrm{CH}_{3}\right)_{2}$ of PNIPAM), 1.28-2.20 (the methylene and methine protons of the polymer backbone), 3.83 (-NHCH$\left(\mathrm{CH}_{3}\right)_{2}$ of PNIPAM), 4.62 (-OCH $\mathrm{CH}_{3}$ of ECTA), 7.01-7.05 (-NH), and 12.30$12.50(-\mathrm{COOH}) ;{ }^{13} \mathrm{C}$ NMR $\delta: 16.7-19.8,24.2,32.8-$ 34.0, 40.6, 46.5, 173.7, and 179.3; and IR (KBr) v $\left[\mathrm{cm}^{-1}\right]: 1172(\mathrm{C}-\mathrm{O}), 1547(\mathrm{~N}-\mathrm{H}), 1651(\mathrm{C}=\mathrm{O}), 1717$ $(\mathrm{C}=\mathrm{O}), 2951,2936(\mathrm{C}-\mathrm{H}), 3300(\mathrm{~N}-\mathrm{H})$, and 3472 $(\mathrm{O}-\mathrm{H})$. 


\subsubsection{Cisplatin loading}

PNIPAM- $b$-MAA ( $80 \mathrm{mg}, 13.3 \mathrm{mmol})$ and cis$\left(\mathrm{Pt}\left[\mathrm{NH}_{3}\right]_{2} \mathrm{Cl}_{2}\right)(19.2 \mathrm{mg}, 64 \mathrm{mmol})$ were placed into a three-neck flask, and the system was evacuated and back-flushed with nitrogen three times. Next, $2 \mathrm{~mL}$ of DMF was injected into the reaction mixture and stirred in an oil bath at $40^{\circ} \mathrm{C}$ for $24 \mathrm{~h}$. Finally, the polymer was precipitated into a $120 \mathrm{~mL}^{\text {of }} \mathrm{Et}_{2} \mathrm{O}$ solution and, following filtration, was washed with the $\mathrm{Et}_{2} \mathrm{O}$ and dried in a vacuum (yield: $58.2 \mathrm{mg}$ ).

\subsection{Determination of critical micelle} concentrations of the Pt@PNIPAM-b-MAA

Four microliters of pyrene stock solution in acetone $(1.26 \mathrm{mM})$ were added to each of a series of $10 \mathrm{~mL}$ volumetric flasks and the acetone was evaporated. Subsequently, $10 \mathrm{~mL}$ of polymer solution with various concentrations ( 0.001 to $2.0 \mathrm{mg} / \mathrm{mL}$ ) was added to each flask, and the $\mathrm{pH}$ of the solutions was adjusted to 7.5 by adding tris(hydroxymethyl)aminomethane. Fluorescence spectra were measured from 360 to $460 \mathrm{~nm}$ following excitation at $339 \mathrm{~nm}$. The intensities of the excitation peaks at 373 and $393 \mathrm{~nm}$ were recorded, and the ratios were plotted as a function of the polymer concentrations.

\subsection{Cell viability assay}

The cytotoxicity of the diblock copolymer was evaluated by determining the cell viability using 3-(4,5-
dimethylthiazol-2-Y1)-2,5-diphenyltetrazolium bromide (MTT) assays. The cells (7F2 osteoblast-like cells) were seeded in 96-well plates at a density of $10^{4}$ cells/well and incubated in a growth medium with different polymer concentrations $(1,35,70$ and $140 \mu \mathrm{g} / \mathrm{mL}(\mathrm{w} / \mathrm{v}))$ for $24 \mathrm{~h}$ at $37^{\circ} \mathrm{C}$. At the end of incubation, $200 \mu \mathrm{L}$ of MTT $(0.1 \mathrm{mg} / \mathrm{mL})$ was added and incubated for $4 \mathrm{~h}$ in an incubator. Subsequently, $200 \mu \mathrm{L}$ of DMSO was added to dissolve formazan and the UV absorbance intensity was measured at $570 \mathrm{~nm}$ using the ELISA reader (Tecan, Infinite M200, Switzerland). All experiments were performed in quadruplicate, and the relative cell viability [\%] was expressed as a percentage relative to the untreated control cells.

\section{Results and discussion}

\subsection{Preparation and kinetic study of microwave-assisted RAFT polymerizations}

The microwave-assisted RAFT polymerization was first tested for NIPAM using ECTA as the CTA and AIBN as the initiator at $65-75^{\circ} \mathrm{C}$. The polymerization mixture was subjected to NMR measurements as a function of polymerization time to obtain the time-conversion curve. Figure 1a showed the change in NIPAM conversion with time for different reaction temperatures. The curve revealed that there was an induction period at first two minutes to activate the polymerization and subsequently, a linear in-
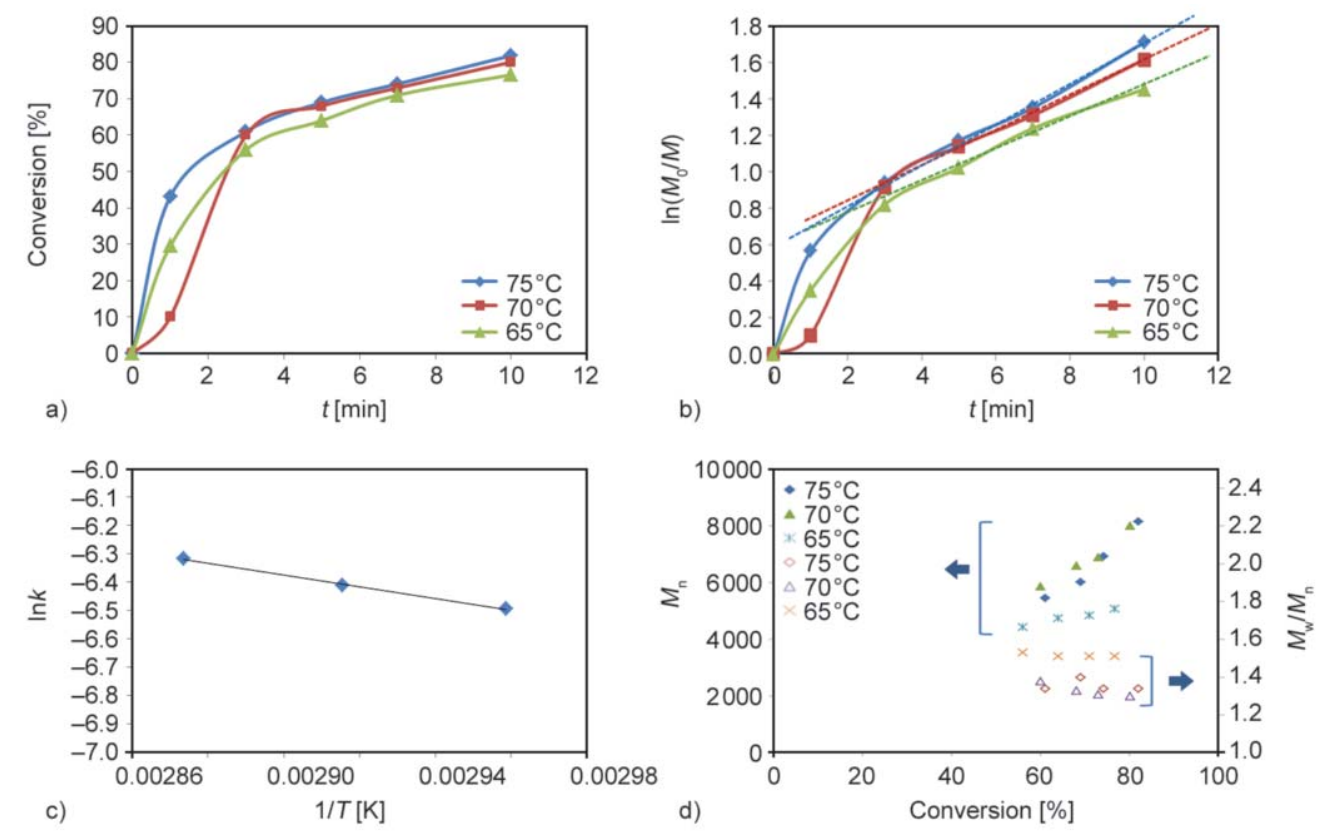

Figure 1. Kinetic plots (a-c) and evaluation (d) of the $M_{\mathrm{n}}$ (solid) and $M_{\mathrm{w}} / M_{\mathrm{n}}$ (hollow) for microwave-assisted RAFT polymerization of NIPAM by using an ECTA CTA in toluene at [NIPAM]/[CTA]/[initiator] = 10/1/0.05 under $100 \mathrm{~W}$ pulsed microwave irradiation 
crease of conversions up to $77-82 \%$ over the reaction time was observed after ten minutes. The induction phenomena is not completely clear so far, however, it might be related to the heating process that the applied microwave energy at the initial reaction stage was mostly consumed to raise the reaction temperature instead of fragmentation of the initial RAFT radical $[38,39]$; or it might be due to the non-uniform superheating of the mixture causing a deviation from zero point. The logarithmic concentration ratio of the monomer $\left(\ln [\mathrm{M}]_{0} /[\mathrm{M}]\right)$ versus the time plots for three temperatures $\left(65,70\right.$, and $\left.75^{\circ} \mathrm{C}\right)$ were also linear after the induction period (Figure 1b), indicating that the concentration of the propagating radicals was essentially constant throughout the polymerization. Therefore, the kinetic plots could be considered pseudo first order reaction and propagation rate constants $k_{\text {app }}$ were determined using the steady state conversions after the induction period. For comparison, the corresponding polymerizations obtained from oil-bath heating were also tested under the same conditions. However, the same catalyst polymerized NIPAM with a similar molecular weight only up to $27 \%$ conversion after $6 \mathrm{~h}$ of oil-bath heating. The propagation rate constant $k_{\text {app }}$ was obtained from the linear regression slope of the pseudo-first-order kinetic plots, and was estimated to be 150 times faster than the conventional heating method. With [NIPAM]/ $[\mathrm{CTA}] /[$ initiator $]=10 / 1 / 0.05$, the relative values of $k_{\text {app }}$ for the polymerizations with microwave heating were $1.51 \times 10^{-3}, 1.64 \times 10^{-3}$, and $1.81 \times 10^{-3} \mathrm{~s}^{-1}$ at 65 , 70 , and $75^{\circ} \mathrm{C}$, respectively, whereas for the conventional heating, it was determined to be $1.17 \times 10^{-5} \mathrm{~s}^{-1}$ at $75^{\circ} \mathrm{C}$. The activation energy, $E_{\mathrm{a}}$, for the RAFT polymerization was estimated as $17.3 \mathrm{~kJ} / \mathrm{mol}$ (Figure $1 \mathrm{c}$ ), which is slightly higher than previously reported data [40]. The molecular weights also increased linearly with the monomer conversion to a dispersity $(\nexists)$ of approximately 1.34 (Figure 1d), indicating that the polymerization remained controlled. However, a relatively high dispersity was observed at $65^{\circ} \mathrm{C}$, which might be attributable to the slow initiation caused by the inefficient decomposition of AIBN at this temperature.

To assess the livingness of the PNIPAM formed in a microwave-assisted system, PNIPAM $\left(M_{\mathrm{n}}=\right.$ approximately $6000 \mathrm{~g} / \mathrm{mol}$ ) was used as a macromolecular RAFT agent for the diblock copolymer synthesis. Depicted in Figures 2, 3 and 4 are the ${ }^{1} \mathrm{H}$ NMR and FTIR spectra of PNIPAM and PNIPAM- $b$-MAA. The ${ }^{1} \mathrm{H}$ NMR spectrum of PNIPAM disclosed two typical signals for the methine protons $\left(-\mathrm{NHCH}\left(\mathrm{CH}_{3}\right)_{2},\right)$ at $\delta=3.99$ and methyl protons $\left(-\mathrm{NHCH}\left(\mathrm{CH}_{3}\right)_{2},\right)$ at $1.13-1.33 \mathrm{ppm}$ as two broad singlet in Figure 2. Other signals such as the methylene protons $(\delta=1.51-1.97 \mathrm{ppm})$ and methine protons $(2.03-2.50 \mathrm{ppm})$ in polymer backbone also agreed with the structure. The ethoxy proton signals from the terminal CTA were observed at $\delta=4.62 \mathrm{ppm}$ ( $-\mathrm{OCH}_{2} \mathrm{CH}_{3}$ of ECTA). In Figure 3 , the copolymers also exhibited the characteristic methine protons of NIPAM $(\boldsymbol{g})$, the acidic protons of MAA $(\boldsymbol{c})$, and ethoxy proton signals of CTA $(i)$. The peak at 3.33 is due to the presence of moisture in DMSO- $d_{6}$, which absorbs moisture very quickly during handling. Moreover, the IR absorptions illustrated in Figure 4

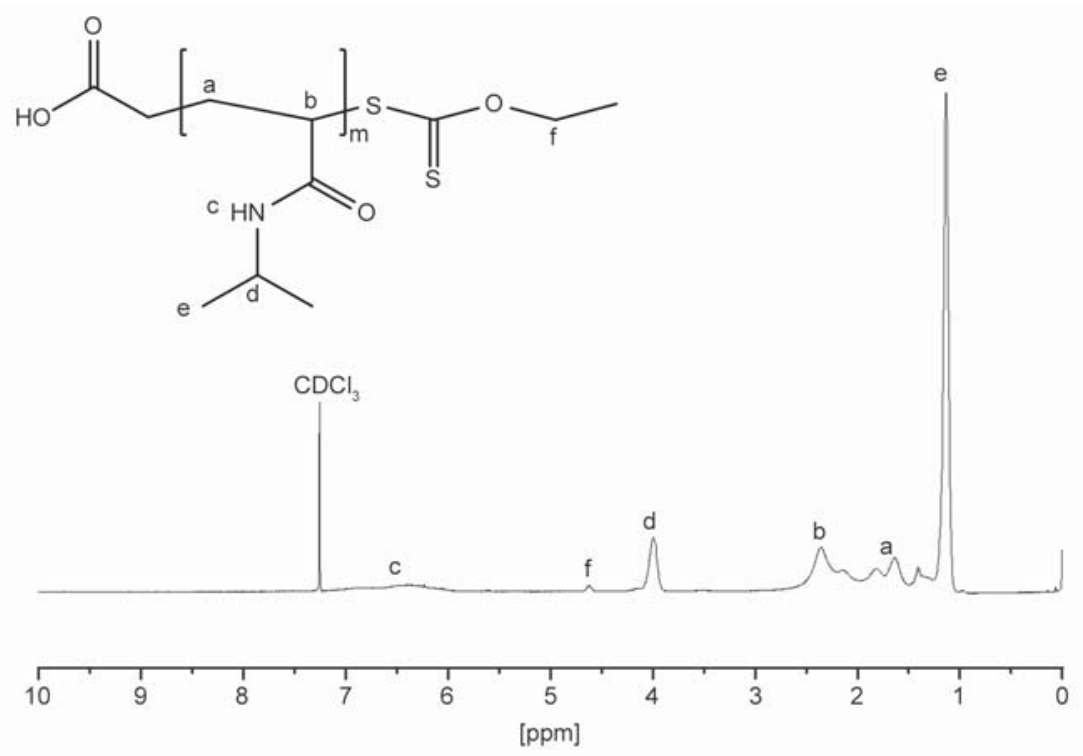

Figure 2. ${ }^{1} \mathrm{H}$ NMR spectra of PNIPAM 


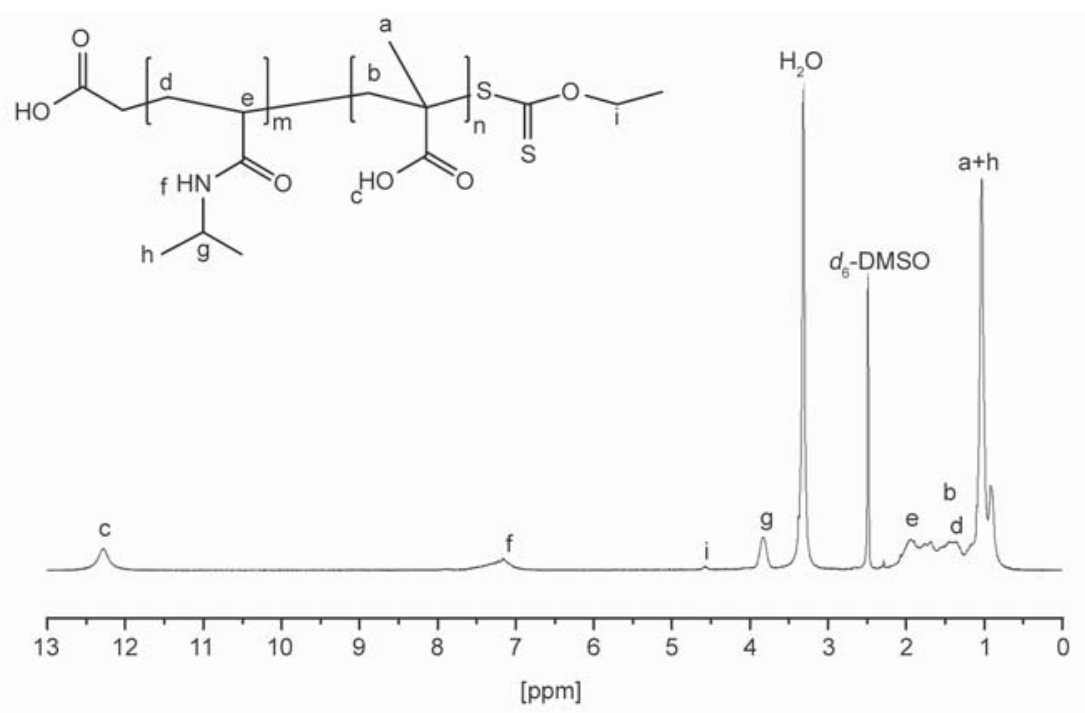

Figure 3. ${ }^{1} \mathrm{H}$ NMR spectra of PNIPAM- $b$-MAA

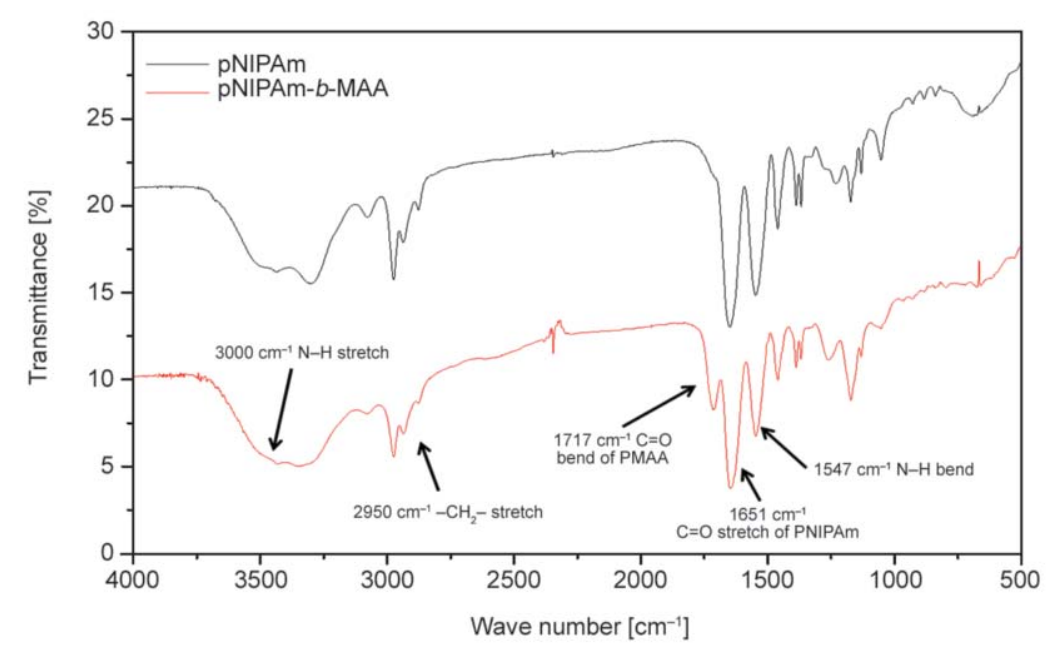

Figure 4. FTIR spectra of PNIPAM and PNIPAM- $b$-MAA

Table 1. Reaction conditions and characterization data of microwave-assisted synthesis (Mixture was irradiated at $75^{\circ} \mathrm{C}$ at $100 \mathrm{~W}$ for $10 \mathrm{~min}$.)

\begin{tabular}{|c|l|l|c|c|c|c|c|c|}
\hline Entry & Monomer & \multicolumn{1}{c|}{ CTA } & {$[\mathbf{M}]_{\mathbf{0}} /[\mathbf{C T A}] /[\mathbf{I}]_{\mathbf{0}}$} & $\boldsymbol{m}: \boldsymbol{n}$ & $\boldsymbol{M}_{\mathbf{n}}{ }^{\mathbf{a}}$ & $\boldsymbol{M}_{\mathbf{w}}$ & $\boldsymbol{D}$ & $\begin{array}{c}\text { LCST } \\
{\left[{ }^{\circ} \mathbf{C}\right]}\end{array}$ \\
\hline 1 & NIPAM & ECTA & $10: 1: 0.05$ & - & 8157 & 10900 & 1.3 & 32 \\
\hline 2 & MAA & PNIPAM & $100: 1: 0.05$ & $1: 1.91$ & 13890 & 21200 & 1.5 & $42-44$ \\
\hline
\end{tabular}

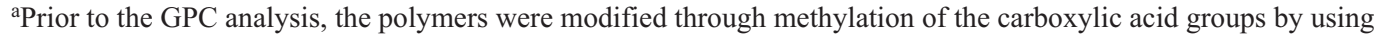
trimethylsilyldiazomethane in DMF at room temperature

at 1717 and $1651 \mathrm{~cm}^{-1}$ can be attributed to the $\mathrm{C}=\mathrm{O}$ stretchings of the carboxylic acid in MAA and the amide in NIPAM, respectively. The molar composition of the NIPAM to MAA was approximately $1: 1.91$, as determined by NMR and titration; the results are summarized in Table 1.

Figure 5 depicts the kinetic plots and molecular weight analysis for the polymerization of PNIPAM- $b$-MAA in DMF and toluene. A slightly longer induction period was observed in Figure 5a, revealing a lower reactivity for the macro-CTA. However, the induction time is still much less than the conventional RAFT polymerization of MAA [41]. After the induction period, linear pseudo-first-order kinetic behavior was observed, indicating that a constant number of radical concentrations were maintained throughout polymerization process. The kinetic plots (Figure 5a and $5 b)$ were consistent with a living polymerization mechanism, and the linear increase in the molecular weight with conversion (Figure 5c) indicated that the polymerization was in a reasonably controlled manner with the $M_{\mathrm{w}} / M_{\mathrm{n}}$ values ranging from 1.4 to 1.6 

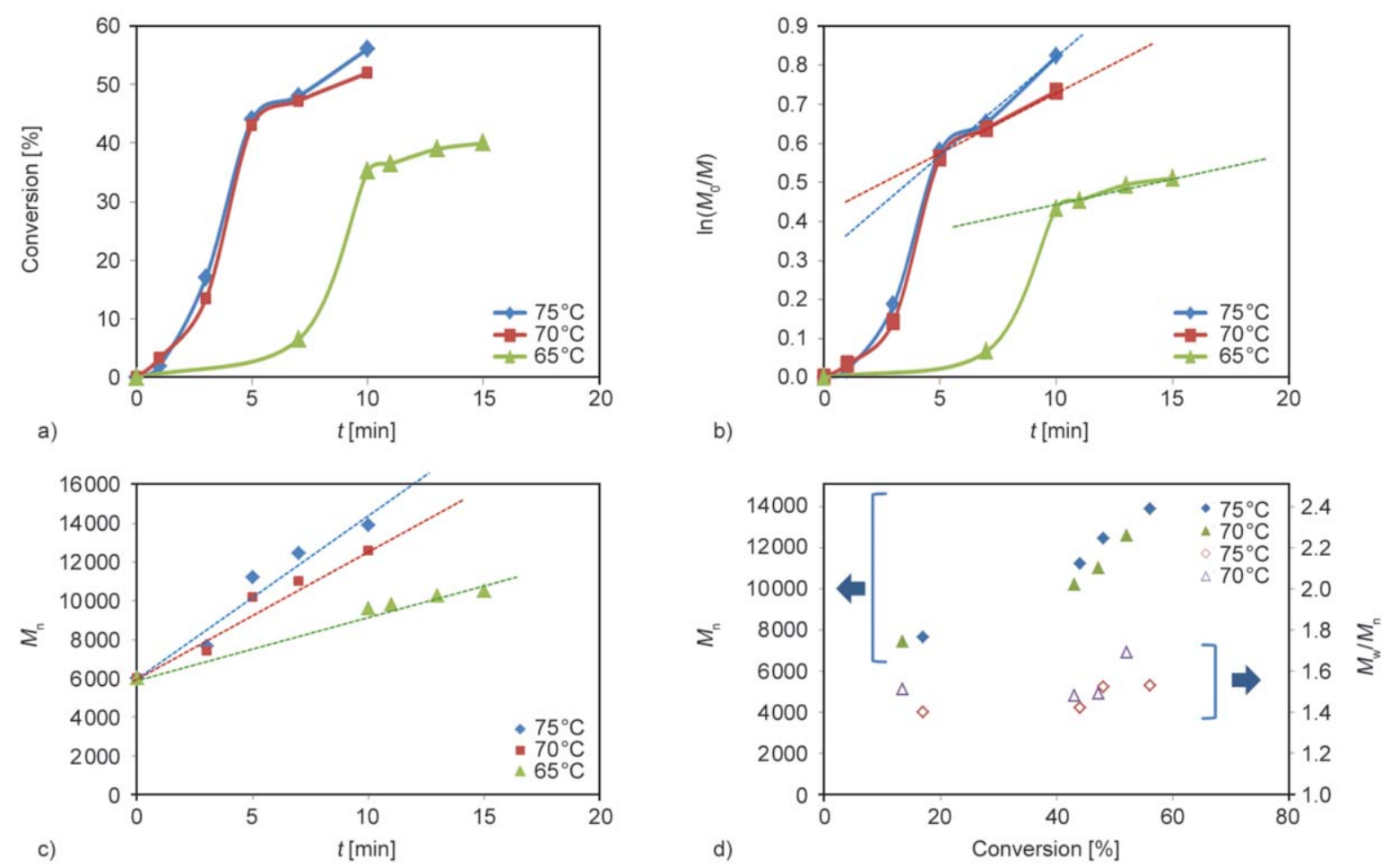

Figure 5. Kinetic plots (a-c) and evaluation (d) of the $M_{\mathrm{n}}$ (solid) and $M_{\mathrm{w}} / M_{\mathrm{n}}$ (hollow) for microwave-assisted RAFT polymerization of MAA by using PNIPAM as the macro-CTA in toluene

(Figure 5d). Additionally, the relative values of kapp for the PNIPAM- $b$-MAA polymerizations with microwave heating were $2.62 \times 10^{-4}, 5.7 \times 10^{-4}$, and $8.22 \times 10^{-4} \mathrm{~s}^{-1}$ at 65,70 , and $75^{\circ} \mathrm{C}$, respectively. The average dispersity of the diblock copolymer (1.46 at $75^{\circ} \mathrm{C}$ ) was slightly higher than that of the PNIPAM $\left(1.35\right.$ at $\left.75^{\circ} \mathrm{C}\right)$, suggesting that some inefficient initiation and termination reactions of the macro-CTA at high conversions cannot be entirely avoided.

\subsection{Stimulus-responsive transition of polymers}

Figures 6 and 7 portray the temperature- and $\mathrm{pH}$-dependent turbidity of the micelle solution through the UV-VIS spectrophotometer results at $600 \mathrm{~nm}$. The transmittance values decreased with increasing temperature, reaching $52 \%$ at $44{ }^{\circ} \mathrm{C}$; furthermore, the transparency of the solution decreased by $40 \%$ when the $\mathrm{pH}$ was adjusted from 8.5 to 3.0. The aggregation was also evidenced by dynamic light scattering data. Figure 8 illustrates the compared particle size distribution of PNIPAM- $b$-MAA as observed at diverse $\mathrm{pH}$ levels and temperatures; notably, the hydrodynamic diameter increased significantly with the temperature, from 25 to $44{ }^{\circ} \mathrm{C}$ at either $\mathrm{pH} 7$ or 4 . In addition, the particle diameter increased as the $\mathrm{pH}$ was decreased from 7 to 4 at different temperatures. The dual-responsive behavior of this polymer is promising for the design of a novel antitumor drug carrier, because it indicates that thermal targeting to the pathological area could occur when tumor tissue is selectively heated to 40 to $44^{\circ} \mathrm{C}$ [42]. Incorporating the MAA component not only resulted in an increase of the lower critical solution temperature (LCST) from 32 to $44^{\circ} \mathrm{C}$, but also induced aggregations in the acidic environment, which responded according to the property required for the extracellular environment of solid tumors and endocytosis conditions [43, 44]. The ability of PNIPAM- $b$-MAA to form micelles in an aqueous solution was tested through fluorescence spectroscopy with pyrene used as a probe. The pyrene was also mixed with polymer solutions at various concentrations, and the emission spectra were recorded [45, 46]. The intensity ratio of the first vibrational band at $373 \mathrm{~nm}$ to the third vibrational band at $393 \mathrm{~nm}$ $\left(I_{373} / I_{393}\right)$ was plotted as a function of the polymer concentrations, as presented in Figure 9. At concentrations above the critical micelle concentration (CMC), $I_{373} / I_{393}$ decreased sharply, indicating micelle formation and partitioning of the pyrene inside the hydrophobic cores of the micelles. Thus, the CMC was estimated to be $0.1 \mathrm{mg} / \mathrm{mL}$ from the sharp drop in the $I_{373} / I_{393}$ ratios. 


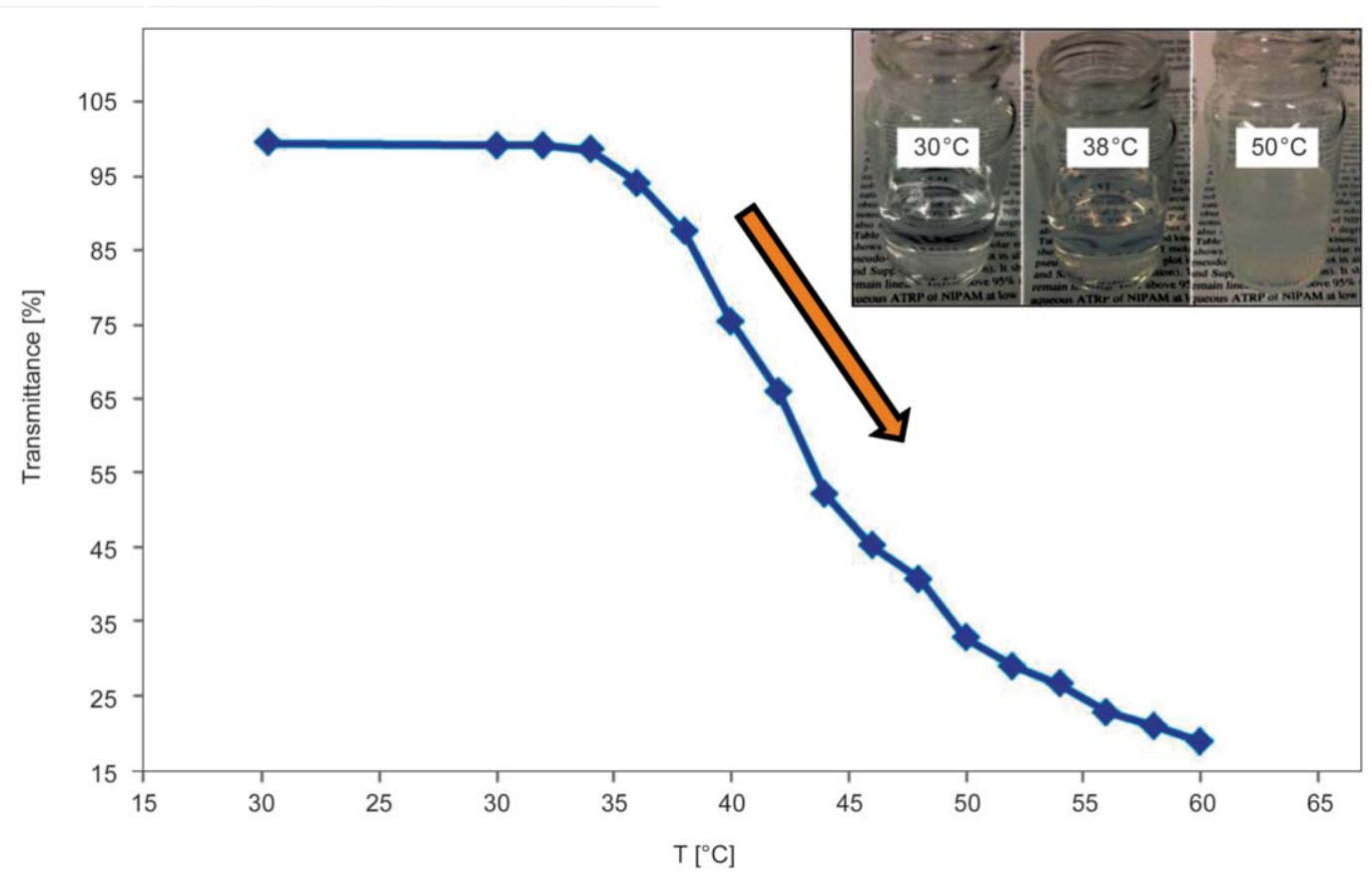

Figure 6. Plot of transmittance [\%] for the aqueous polymer solutions $(2 \mathrm{mg} / \mathrm{mL})$ as a function of the temperature at $600 \mathrm{~nm}$ for PNIPAM- $b$-MAA

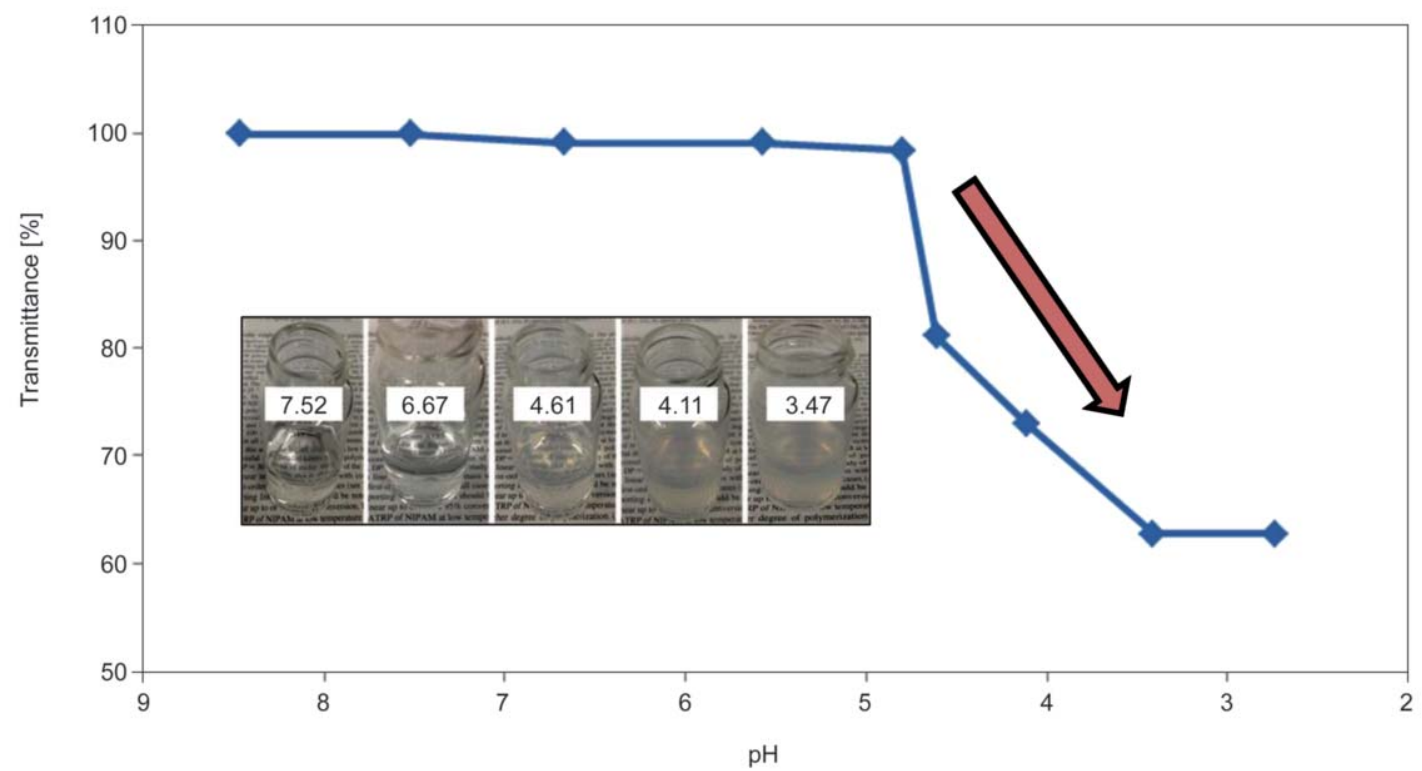

Figure 7. Plots of transmittance [\%] of aqueous polymer solutions $(1 \mathrm{mg} / \mathrm{mL})$ as a function of $\mathrm{pH}$ at $600 \mathrm{~nm}$ for PNIPAM$b$-MAA

\subsection{Preparation of the cisplatin-loaded polymer conjugate}

The conjugation of cisplatin to PNIPAM- $b$-MAA was achieved through a ligand exchange between the chloride ion and carboxylate groups in either a monofunctional, bifunctional, or interchain crosslinking manner, as depicted in Figure 10. The FTIR spectra verified the conjugation between the polymer and cisplatin, as indicated in Figure 11. The spectra also exhibited two pronounced peaks at 3292 and $1385 \mathrm{~cm}^{-1}$, revealing the absorptions of $\mathrm{N}-\mathrm{H}$ stretching from cisplatin ligands $\left(\mathrm{Pt}-\mathrm{NH}_{2}\right)$, and the chelation of the COO-Pt stretch, respectively $[47,48]$. In addition, a reduction in absorbance of the carbonyl $(\mathrm{C}=\mathrm{O})$ stretch of $\mathrm{COOH}$ at $1704 \mathrm{~cm}^{-1}$ relative to the amide $\mathrm{C}=\mathrm{O}$ band at $1633 \mathrm{~cm}^{-1}$ (the difference between relative intensity in (a) and (b) in Figure 11) is consistent with the prediction that some of the $-\mathrm{COOH}$ groups would react with the Pt atoms in a ligand exchange reaction [49]. Dynamic light scattering was also employed to confirm size changes in the polymer induced by the conjugation (Figure 12).The average 


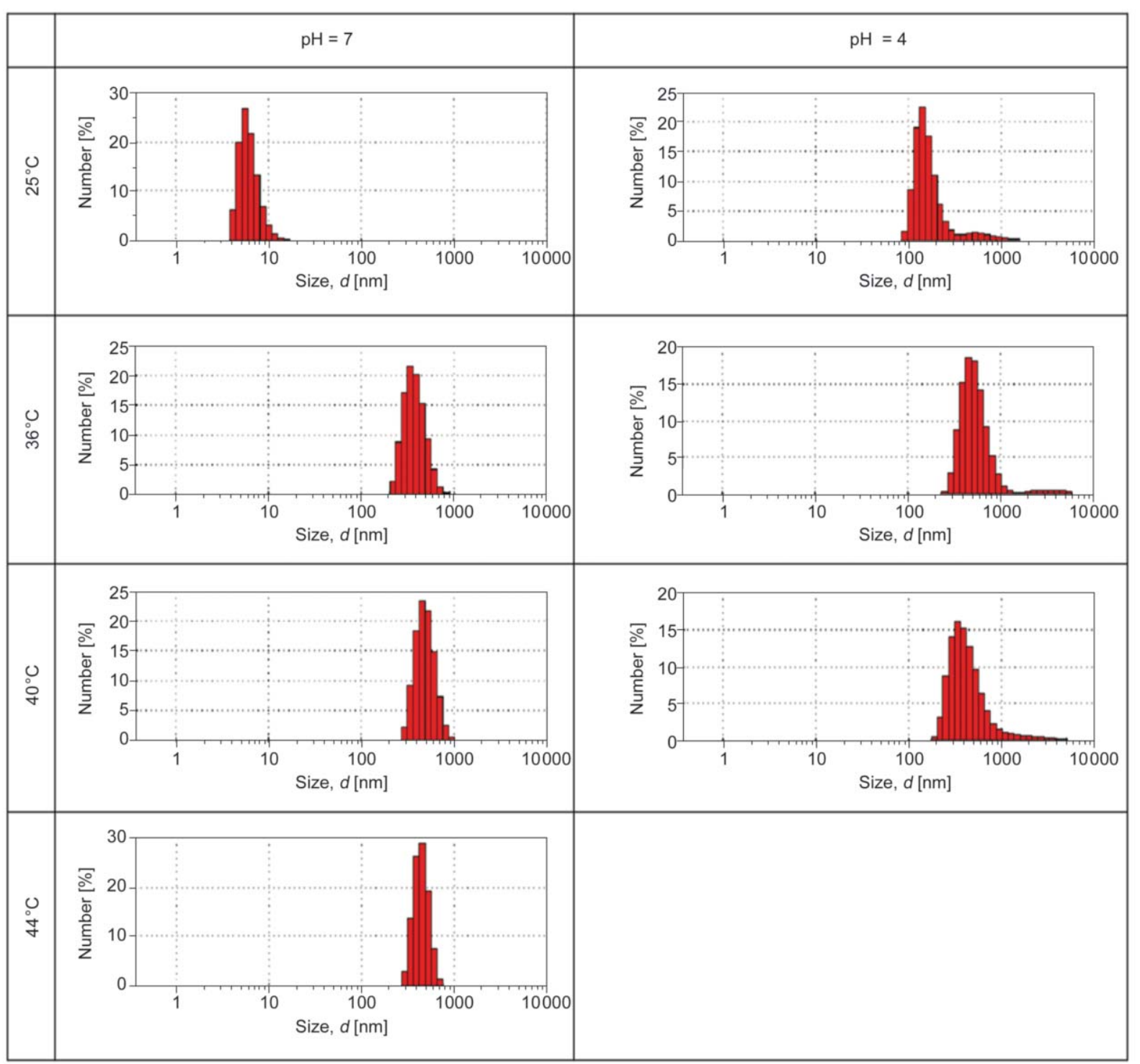

Figure 8. Number-averaged particle size distributions of the PNIPAM- $b$-MAA in an aqueous solution with a concentration of $0.1 \mathrm{mg} / \mathrm{mL}$

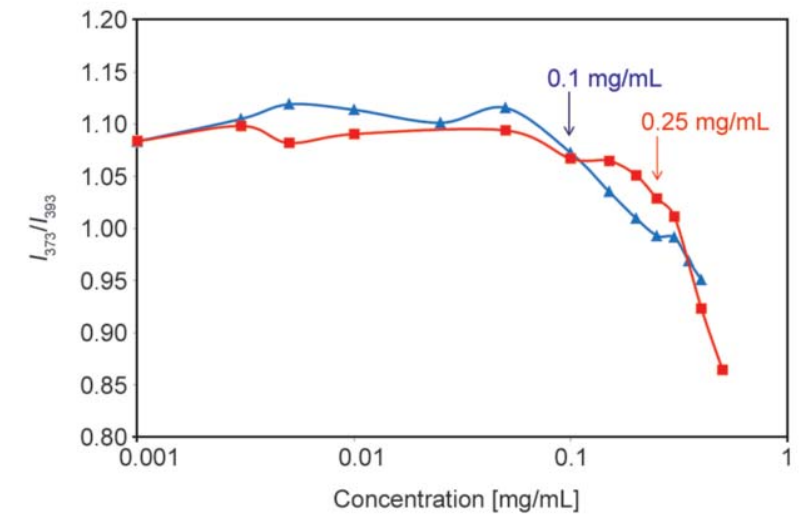

Figure 9. Relationship between the intensity ratio $\left(I_{373} / I_{393}\right)$ of pyrene emission spectra $\left(\lambda_{\mathrm{ex}}=339 \mathrm{~nm}\right)$ and the concentration of PNIPAM- $b$-MAA ( $\boldsymbol{\Delta})$ and Pt@PNIPAM- $b$-MAA $(\mathbf{\square})$ at $25^{\circ} \mathrm{C}$ in an aqueous solution with $\mathrm{pH} 7.5$ hydrodynamic diameter of the polymer increased from approximately 210 to $280 \mathrm{~nm}$ after Pt conjugation, indicating an interchain crosslinking of polymer chains by Pt within the polymer chains. Figure 13a shows the TEM images of micelles obtained by selfassembly of Pt@PNIPAM- $b$-MAA in aqueous solution. The particle sizes of the Pt@PNIPAM- $b$-MAA at $25^{\circ} \mathrm{C}$ were approximately $100-200 \mathrm{~nm}$ with almost spherical core-shell structures. The cisplatin-loaded polymer conjugate self-assembled into almost spherical micelles without any particular formulation. We believe that the intrachain cross-linking forming a short rigid block might help generating the hydrophobic core structure of PMAA and leave the hydrophilic PNIPAM on outer surface at room temperature (below LCST). Figure 13b shows an Energy-dispersive X-ray 
<smiles>C=CC(=O)NC(C)C</smiles>

$\mathrm{N}$-isopropylacrylamide
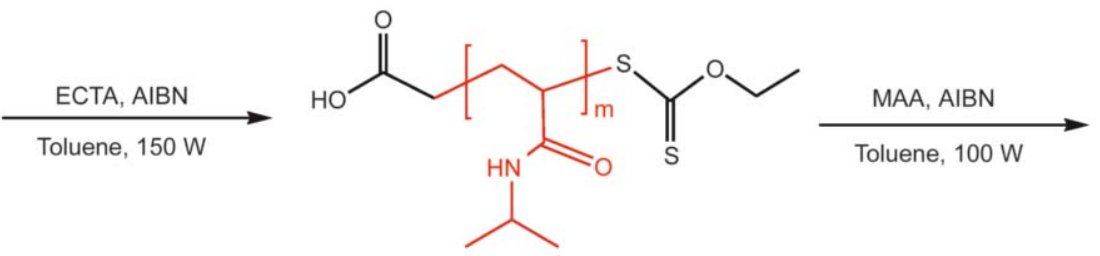

Poly(N-isopropylacrylamide)

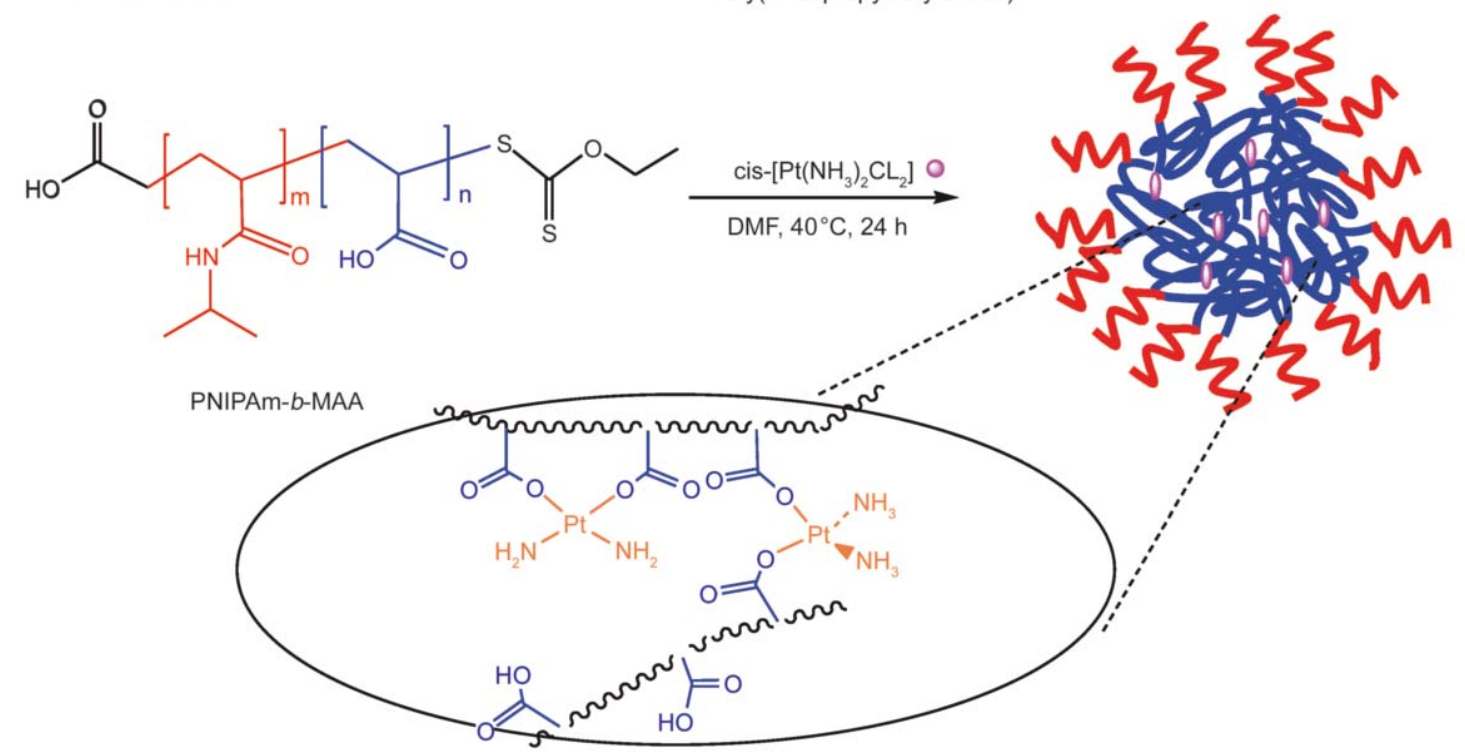

Pt@PNIPAm-b-MAA

Figure 10. Schematic description of the polymer-cisplatin prodrug conjugate synthesis

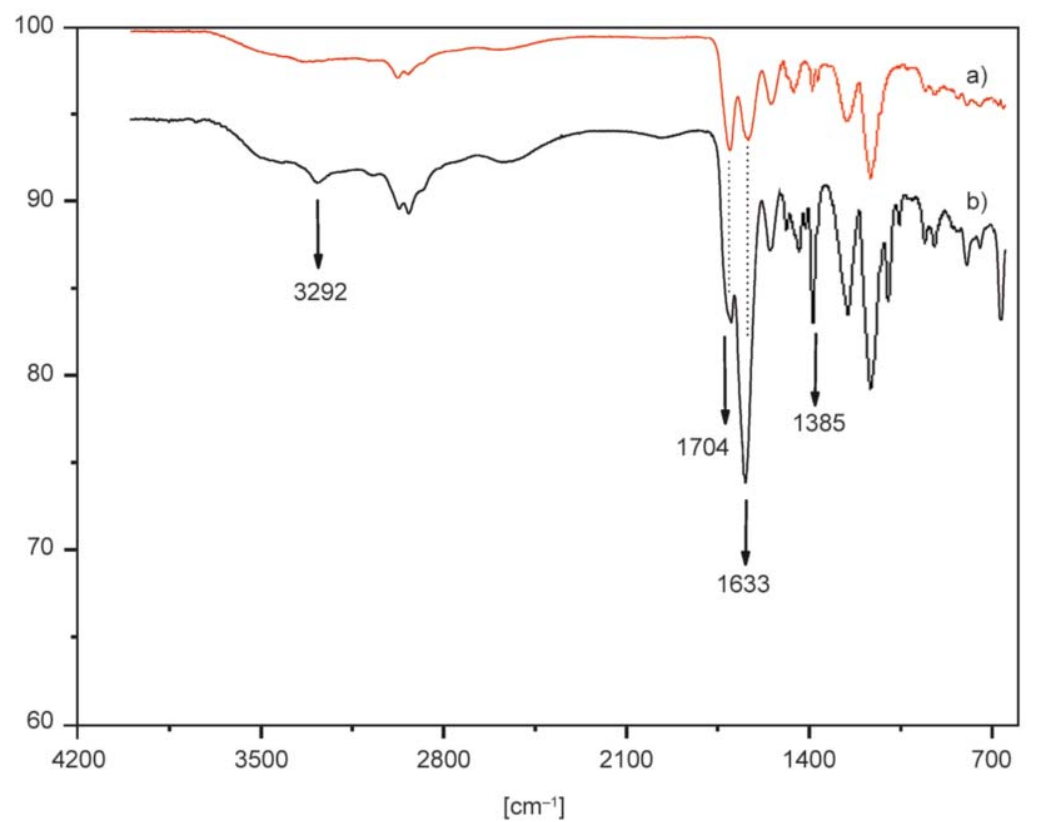

Figure 11. FTIR spectra of PNIPAM- $b$-MAA (a) and its corresponding drug conjugate Pt@ PNIPAM- $b$-MAA (b)

spectroscopy (EDS) spectrum which displayed a platinum content of $12.2 \mathrm{wt} \%$. ICP-MS also confirmed that the content of $\mathrm{Pt}$ in polymer conjugate was $11.2 \mathrm{wt} \%$ which indicated a strong drug-loading capacity, considering that the feed ratio of platinum to copolymer was only $12.6 \mathrm{wt} \%$. The cisplatin-entrapped polymer conjugate retained adequate solubility at normal physiological $\mathrm{pH}$ condition and 


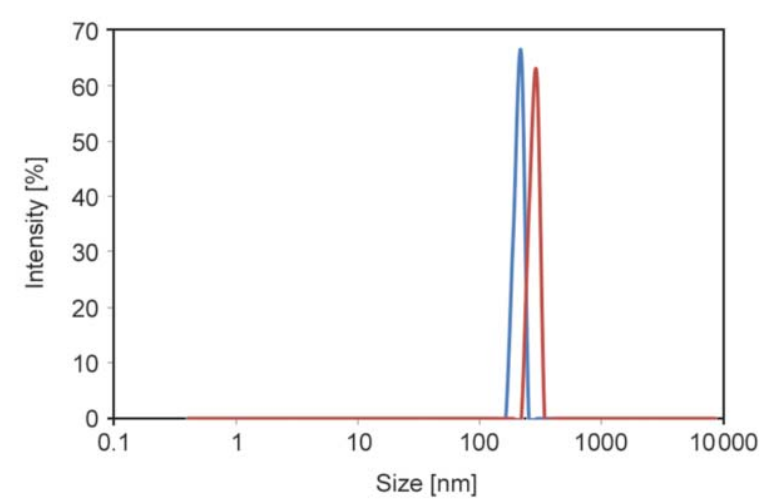

Figure 12. Number-averaged particle size distributions of the PNIPAM- $b$-MAA at $25^{\circ} \mathrm{C}$ (blue line), and the Pt@PNIPAM- $b$-MAA (red line) in an aqueous solution with a concentration of $0.1 \mathrm{mg} / \mathrm{mL}$ after cisplatin conjugation

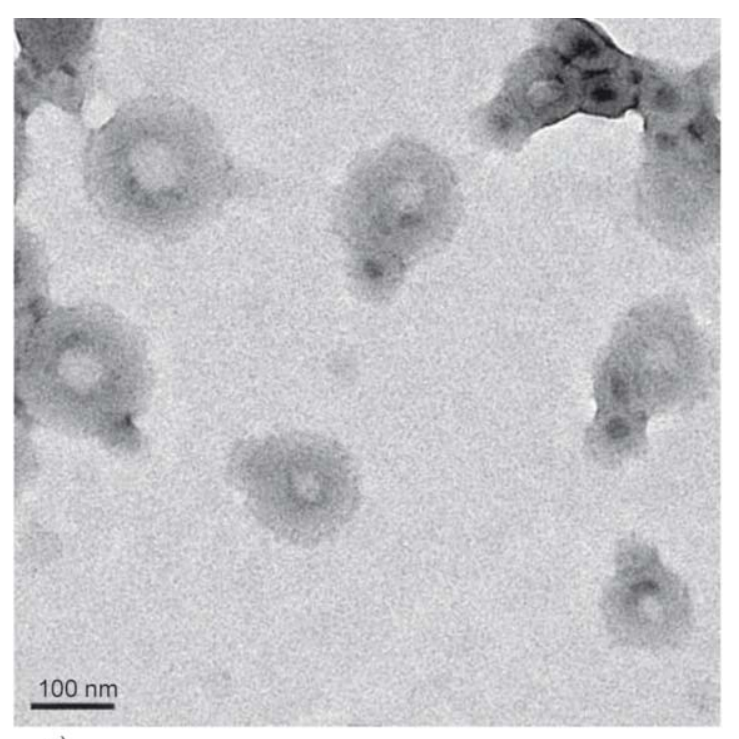

a)

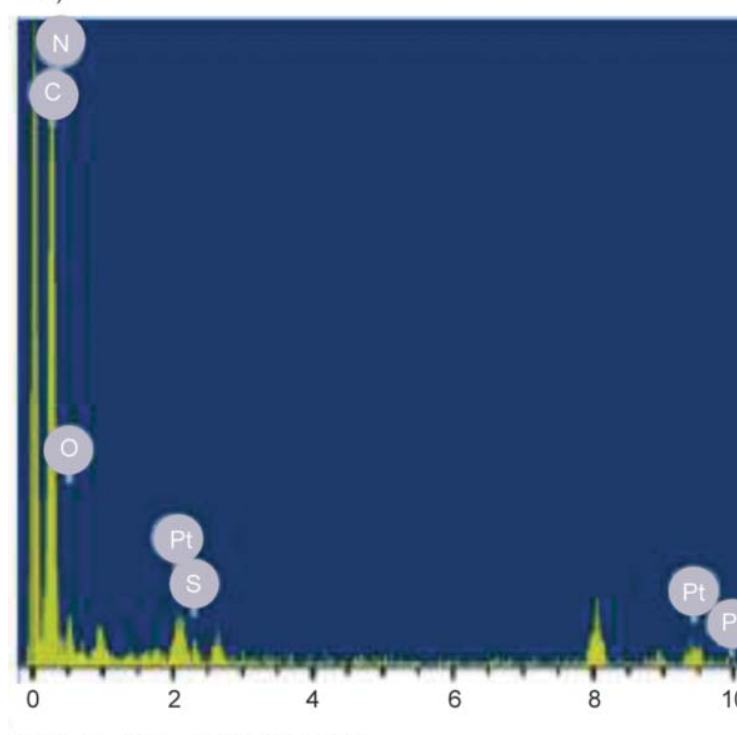

Full scale 159 cts Cursor: 0.000

c)

Figure 13. The TEM images of Pt@ PNIPAM- $b$-MAA prepared by the solvent evaporation method at polymer concentration of $0.3 \mathrm{mg} / \mathrm{mL}$ in aqueous solution $(\mathrm{a}, \mathrm{b})$ and EDS analysis of the prepared core-shell micelle (c) formed micelles at a CMC value of $0.25 \mathrm{mg} / \mathrm{mL}$, as shown in Figure 9. The cytotoxicity of the diblock copolymer,Pt@PNIPAM- $b$-MAA, and free cisplatin was measured using an MTT assay. The effect of PNIPAM- $b$-MAA concentrations on cell viability of 7F2 osteoblast-like cells is shown in Figure 14. Polymers reduced cell viability by approximately $10-20 \%$ from 1 to $70 \mu \mathrm{g} / \mathrm{mL}$ comparing to the control sample whereas a significant viability reduction at $140 \mu \mathrm{g} / \mathrm{mL}$ was observed. Therefore, the polymer concentration $70 \mu \mathrm{g} / \mathrm{mL}$ was chosen for the cytotoxicity against 7F2 osteoblast-like cells. Figure 15 showed that the blank copolymer did not exhibit appreciable cytotoxicity, indicating that its biocompatibility is suffi-

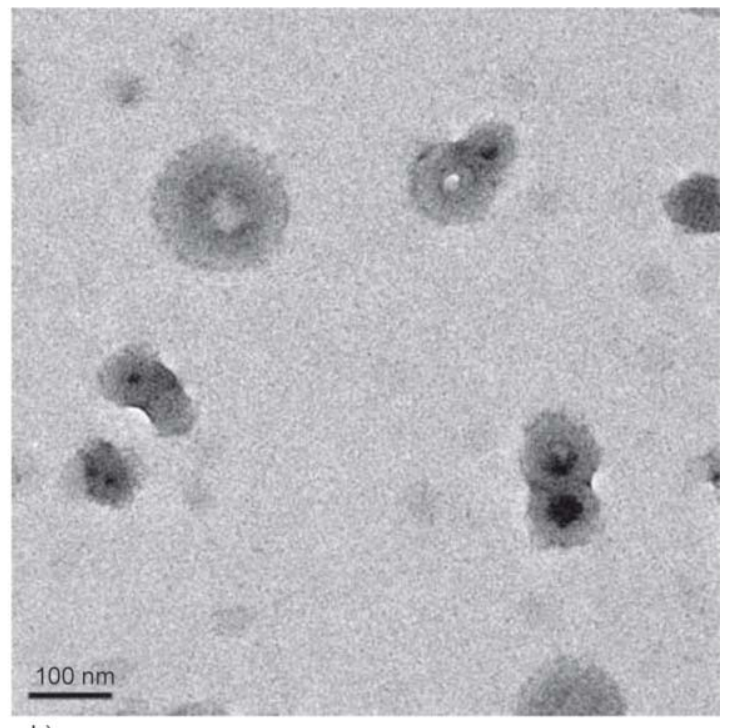

b)

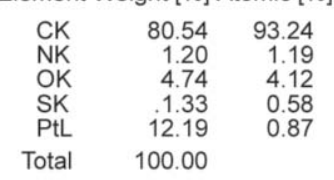




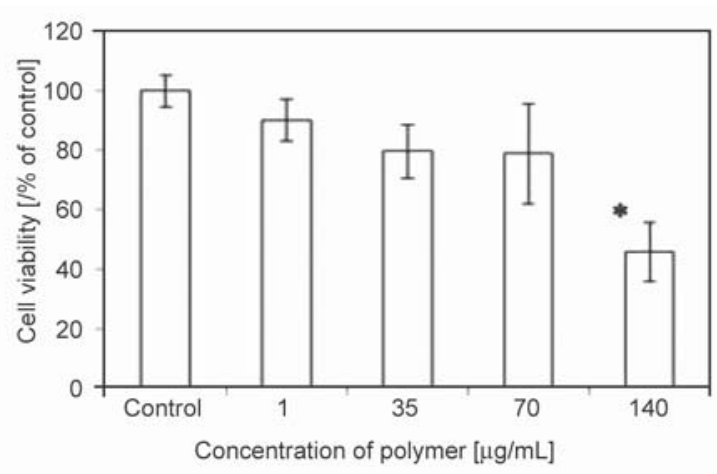

Figure 14. The effect of polymer concentrations on cell viability of 7F2 osteoblast-like cells. Data are expressed by the mean of percent cell viability compared to control \pm standard deviation $(n=6)$. ${ }^{*} p<0.05$, compared to control.

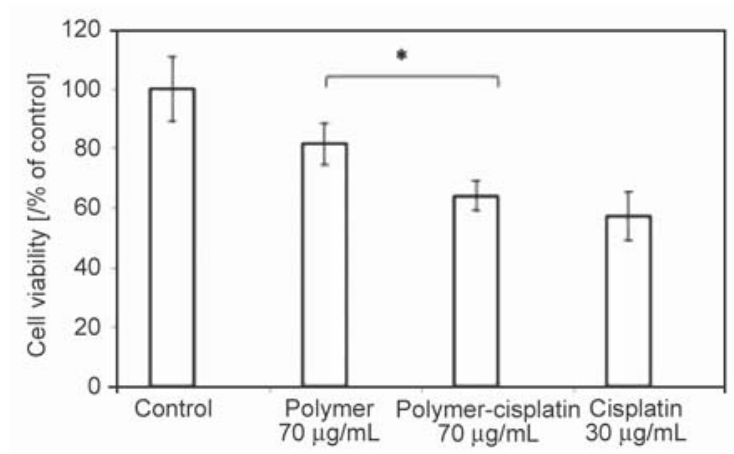

Figure 15. The cell viability of 7F2 osteoblast-like cells treated with polymers, polymer-Cisplatin conjugates and free drugs. Data are expressed by the mean of percent cell viability compared to control \pm standard deviation $(n=6) . * p<0.05$, compared to the cells treated with polymers alone.

ciently high for in vivo applications. On the other hand, the cisplatin conjugated polymer and free cisplatin drug reduced cell viability by approximately 36.1 and $42.8 \%$, respectively. Considering the $\mathrm{Pt}$ metal entrapped in polymer conjugate was only $12.6 \mathrm{wt} \%$, the result suggested that the efficacy of the Pt@PNIPAM- $b$-MAA was comparable to that of the free cisplatin and the conjugation with the amphiphilic copolymer did not compromise its cytotoxic activity.

\section{Conclusions}

The use of various pharmaceutical nanocarriers has become one of the most studied areas of nanomedicine. In the present study, we examined the synthesis of a fast microwave-assisted polymeric drug carrier featuring both $\mathrm{pH}$ and temperature responsiveness through RAFT polymerization. Through the use ECTA as the CTA and AIBN as the initiator, the polymerizations exhibited living polymerization features such as a linear relationship between $M_{\mathrm{n}}$ and the conver- sion, a controlled molecular weight, and a relatively narrow molecular weight distribution. Furthermore, the values of $k_{\text {app }}$ demonstrated that our microwaveassisted process was approximately 150 times faster than those observed under conventional heating conditions, where [NIPAM]/[CTA]/[initiator] = 10/1/0.05. Reactivating the PNIPAM as a macro-RAFT agent for MAA copolymerization produced a diblock copolymer PNIPAM- $b$-MAA that did not lose its 'living' nature under the microwave irradiation. Increasing the temperature above $40^{\circ} \mathrm{C}$ or reducing the $\mathrm{pH}$ of the solution can generate various degrees of aggregations, which are ideal for drug accumulation control in the design of new antitumor drug delivery systems. Theoretically, various anticancer polymeric drug conjugates could be accessible through the replacement of different drug molecules. These polymeric micelles are expected to possess high potential for antitumor drug delivery because of a strong combination of passive targeting characteristics (i.e., the enhanced permeability and retention effect) and the sensitivity to either temperature or acidic microenvironments.

\section{Acknowledgements}

The authors gratefully acknowledge the financial support provided by the Ministry of Science and Technology (NSC 102-2113-M-415-003) of Taiwan, R.O.C.

\section{References}

[1] Keddie D. J.: A guide to the synthesis of block copolymers using reversible-addition fragmentation chain transfer (RAFT) polymerization. Chemical Society Reviews, 43, 496-505 (2014). https://doi.org/10.1039/c3cs60290g

[2] Fairbanks B. D., Gunatillake P. A., Meagher L.: Biomedical applications of polymers derived by reversible addition - fragmentation chain-transfer (RAFT). Advanced Drug Delivery Reviews, 91, 141-152 (2015). https://doi.org/10.1016/j.addr.2015.05.016

[3] Moad G., Rizzardo E., Thang S. H.: RAFT polymerization and some of its applications. Chemistry: An Asian Journal, 8, 1634-1644 (2013). https://doi.org/10.1002/asia.201300262

[4] Santagada V., Frecentese F., Perissutti E., Fiorino F., Severino B., Caliendo G.: Microwave assisted synthesis: Technology in drug discovery. Mini-Reviews in Medicinal Chemistry, 9, 340-358 (2009).

[5] Leonetti F., Capaldi C., Carotti A.: Microwave-assisted solid phase synthesis of Imatinib, a blockbuster anticancer drug. Tetrahedron Letters, 48, 3455-3458 (2007). https://doi.org/10.1016/j.tetlet.2007.03.033 
[6] Gising J., Odell L. R., Larhed M.: Microwave-assisted synthesis of small molecules targeting the infectious diseases tuberculosis, HIV/AIDS, malaria and hepatitis C. Organic and Biomolecular Chemistry, 10, 2713 2729 (2012).

https://doi.org/10.1039/C2OB06833H

[7] Manetti F., Esté J. A., Clotet-Codina I., Armand-Ugón M., Maga G., Crespan E., Cancio R., Mugnaini C., Bernardini C., Togninelli A., Carmi C., Alongi M., Petricci E., Massa S., Corelli F., Botta M.: Parallel solution-phase and microwave-assisted synthesis of new S-DABO derivatives endowed with subnanomolar antiHIV-1 activity. Journal of Medicinal Chemistry, 48, 8000-8008 (2005).

https://doi.org/10.1021/JM050744T

[8] Mahalingam A. K., Axelsson L., Ekegren J. K., Wannberg J., Kihlström J., Unge T., Wallberg H., Samuelsson B., Larhed M., Hallberg A.: HIV-1 protease inhibitors with a transition-state mimic comprising a tertiary alcohol: Improved antiviral activity in cells. Journal of Medicinal Chemistry, 53, 607-615 (2010). https://doi.org/10.1021/JM901165G

[9] Barreca M. L., Ferro S., Rao A., De Luca L., Zappalà M., Monforte A-M., Debyser Z., Witvrouw M., Chimirri A.: Pharmacophore-based design of HIV-1 integrase strand-transfer inhibitors. Journal of Medicinal Chemistry, 48, 7084-7088 (2005).

https://doi.org/10.1021/JM050549E

[10] Toque H. A. F., Priviero F. B. M., Teixeira C. E., Perissutti E., Fiorino F., Severino B., Frecentese F., Lorenzetti R., Baracat J. S., Santagada V., Caliendo G., Antunes E., De Nucci G.: Synthesis and pharmacological evaluations of sildenafil analogues for treatment of erectile dysfunction. Journal of Medicinal Chemistry, 51, 2807 2815 (2008).

https://doi.org/10.1021/JM701400R

[11] Harju K., Vesterinen J., Yli-Kauhaluoma J.: Solid-phase synthesis of amino acid derived $N$-unsubstituted pyrazoles via sydnones. Organic Letters, 11, 2219-2221 (2009). https://doi.org/10.1021/OL900704B

[12] Steenackers H. P. L., Ermolat'ev D. S., Savaliya B., De Weerdt A., De Coster D., Shah A., Van der Eycken E. V., De Vos D. E, Vanderleyden J., De Keersmaecker S. C. J.: Structure-activity relationship of 4(5)-aryl-2amino-1H-imidazoles, N1-substituted 2-Aminoimidazoles and imidazo[1,2-a]pyrimidinium salts as inhibitors of biofilm formation by salmonella typhimurium and pseudomonas aeruginosa. Journal of Medicinal Chemistry, 54, 472-484 (2011). https://doi.org/10.1021/JM1011148

[13] Ghani S. B. A., Weaver L., Zidan Z. H., Ali H. M., Keevil C. W., Brown R. C. D.: Microwave-assisted synthesis and antimicrobial activities of flavonoid derivatives. Bioorganic and Medicinal Chemistry Letters, 18, 518-522 (2008).

https://doi.org/10.1016/J.BMCL.2007.11.081
[14] Fridén-Saxin M., Seifert T., Landergren M. R., Suuronen T., Lahtela-Kakkonen M., Jarho E. M., Luthman K.: Synthesis and evaluation of substituted chroman-4one and chromone derivatives as sirtuin 2-selective inhibitors. Journal of Medicinal Chemistry, 55, 71047113 (2012).

https://doi.org/10.1021/JM3005288

[15] Wu J., Zhang D., Chen L., Li J., Wang J., Ning C., Yu N., Zhao F., Chen D., Chen X., Chen K., Jiang H., Liu H., Liu D.: Discovery and mechanism study of SIRT1 activators that promote the deacetylation of fluorophore-labeled substrate. Journal of Medicinal Chemistry, 56, 761-780 (2013).

https://doi.org/10.1021/JM301032J

[16] Larhed M., Moberg C., Hallberg A.: Microwave-accelerated homogeneous catalysis in organic chemistry. Accounts of Chemical Research, 35, 717-727 (2002). https://doi.org/10.1021/AR010074V

[17] Testero S. A., Mata E. G.: Prospect of metal-catalyzed $\mathrm{C}-\mathrm{C}$ forming cross-coupling reactions in modern solidphase organic synthesis. Journal of Combinatorial Chemistry, 10, 487-497 (2008). https://doi.org/10.1021/CC800020B

[18] Tu Z., Efange S. M. N., Xu J., Li S., Jones L. A., Parsons S. M., Mach R. H.: Synthesis and in vitro and in vivo evaluation of ${ }^{18} \mathrm{~F}$-labeled positron emission tomography (PET) ligands for imaging the vesicular acetylcholine transporter. Journal of Medicinal Chemistry, 52, 1358-1369 (2009). https://doi.org/10.1021/JM8012344

[19] Velikyan I., Beyer G. J., Långström B.: Microwavesupported preparation of ${ }^{68} \mathrm{Ga}$ bioconjugates with high specific radioactivity. Bioconjugate Chemistry, 15, 554-560 (2004). https://doi.org/10.1021/BC030078F

[20] Lehmann H., LaVecchia L.: Scale-up of organic reactions in a pharmaceutical kilo-lab using a commercial microwave reactor. Organic Process Research and Development, 14, 650-656 (2010). https://doi.org/10.1021/OP900269Y

[21] Dallinger D., Lehmann H., Moseley J. D., Stadler A., Kappe C. O.: Scale-up of microwave-assisted reactions in a multimode bench-top reactor. Organic Process Research and Development, 15, 841-854 (2011). https://doi.org/10.1021/OP200090K

[22] Kempe K., Becer C. R., Schubert U. S.: Microwave-assisted polymerizations: Recent status and future perspectives. Macromolecules, 44, 5825-5842 (2011). https://doi.org/10.1021/MA2004794

[23] Sosnik A., Gotelli G., Abraham G. A.: Microwave-assisted polymer synthesis (MAPS) as a tool in biomaterials science: How new and how powerful. Progress in Polymer Science, 36, 1050-1078 (2011). https://doi.org/10.1016/J.PROGPOLYMSCI.2010.12.001

[24] Hoogenboom R., Schubert U. S., Wiesbrock F.: Microwave-assisted polymer synthesis. Advances in Polymer Science, 274, 45-241 (2016).

https://doi.org/10.1007/978-3-319-42241-1 
[25] Komorowska-Durka M., Dimitrakis G., Bogdal D., Stankiewicz A. I., Stefanidis G. D.: A concise review on microwave-assisted polycondensation reactions and curing of polycondensation polymers with focus on the effect of process conditions. Chemical Engineering Journal, 264, 633-644 (2015).

https://doi.org/10.1016/j.cej.2014.11.087

[26] Zhang C., Liao L., Gong S.: Recent developments in microwave-assisted polymerization with a focus on ringopening polymerization. Green Chemistry, 9, 303-314 (2007).

https://doi.org/10.1039/b608891k

[27] Singla P., Mehta R., Berek D., Upadhyay S. N.: Ring opening polymerization of lactide in a monomode microwave using stannous octoate and dibutyltin dimethoxide catalysts. Journal of Macromolecular Science Part A: Pure and Applied Chemistry, 51, 350-361 (2014). https://doi.org/10.1080/10601325.2014.882701

[28] Cheng Z., Zhu X., Zhou N., Zhu J., Zhang Z.: Atom transfer radical polymerization of styrene under pulsed microwave irradiation. Radiation Physics and Chemistry, 72, 695-701 (2005).

https://doi.org/10.1016/j.radphyschem.2004.04.134

[29] Buruiana E. C., Murariu M., Buruiana T.: Copolyacrylates with phenylalanine and anthracene entities prepared by ATRP and microwave irradiation. Journal of Luminescence, 130, 1794-1801 (2010).

https://doi.org/10.1016/j.jlumin.2010.04.012

[30] Rigolini J., Grassl B., Reynaud S., Billon L.: Microwave-assisted nitroxide-mediated polymerization for water-soluble homopolymers and block copolymers synthesis in homogeneous aqueous solution. Journal of Polymer Science Part A: Polymer Chemistry, 48, 57755782 (2010).

https://doi.org/10.1002/pola.24385

[31] Li J., Zhu X., Zhu J., Cheng Z.: Microwave-assisted nitroxide-mediated radical polymerization of styrene. Radiation Physics and Chemistry, 75, 253-258 (2006). https://doi.org/10.1016/j.radphyschem.2005.06.006

[32] Brooks W. L. A., Sumerlin B. S.: Microwave-assisted RAFT polymerization. Israel Journal of Chemistry, 52, 256-263 (2012).

https://doi.org/10.1002/ijch.201100140

[33] Roy D., Ullah A., Sumerlin B. S.: Rapid block copolymer synthesis by microwave-assisted RAFT polymerization. Macromolecules, 42, 7701-7708 (2009). https://doi.org/10.1021/MA901471K

[34] An Z., Shi Q., Tang W., Tsung C-K., Hawker C. J., Stucky G. D.: Facile RAFT precipitation polymerization for the microwave-assisted synthesis of well-defined, double hydrophilic block copolymers and nanostructured hydrogels. Journal of the American Chemical Society, 129, 14493-14499 (2007).

https://doi.org/10.1021/JA0756974
[35] Özdemir Z., Topuzoğulları M., İşoğlu İ. A., Dinçer S.: RAFT-mediated synthesis of poly( $N$-(2-hydroxypropyl) methacrylamide- $b$-4-vinylpyridine) by conventional and microwave heating. Polymer Bulletin, 70, 2857-2872 (2013).

https://doi.org/10.1007/S00289-013-0993-1

[36] Assem Y., Greiner A., Agarwal S.: Microwave-assisted controlled ring-closing cyclopolymerization of diallyldimethylammonium chloride via the RAFT process. Macromolecular Rapid Communications, 28, 19231928 (2007). https://doi.org/10.1002/MARC.200700377

[37] Stenzel M. H., Cummins L., Roberts G. E., Davis T. P., Vana P., Barner-Kowollik C.: Xanthate mediated living polymerization of vinyl acetate: A systematic variation in MADIX/RAFT agent structure. Macromolecular Chemistry and Physics, 204, 1160-1168 (2003). https://doi.org/10.1002/MACP.200390089

[38] Convertine A. J., Lokitz B. S., Lowe A. B., Scales C. W., Myrick L. J., McCormick C. L.: Aqueous RAFT polymerization of acrylamide and $\mathrm{N}, \mathrm{N}$-dimethylacrylamide at room temperature. Macromolecular Rapid Communications, 26, 791-795 (2005).

https://doi.org/10.1002/marc.200500042

[39] Luo J., Li M., Xin M., Sun W.: Benzoyl peroxide/2vinylpyridine synergy in RAFT polymerization: Synthesis of poly(2-vinylpyridine) with low dispersity at ambient temperature. Macromolecular Chemistry and Physics, 216, 1646-1652 (2015).

https://doi.org/10.1002/macp.201500156

[40] Chee C. K., Rimmer S., Shaw D. A., Soutar I., Swanson L.: Manipulating the thermoresponsive behavior of poly(n-isopropylacrylamide). 1. On the conformational behavior of a series of $N$-isopropylacrylamide-styrene statistical copolymers. Macromolecules, 34, 7544-7549 (2001).

https://doi.org/10.1021/MA010360M

[41] Pelet J. M., Putnam D.: High molecular weight poly (methacrylic acid) with narrow polydispersity by RAFT polymerization. Macromolecules, 42, 1494-1499 (2009). https://doi.org/10.1021/ma801433g

[42] Meyer D. E., Shin B. C., Kong G. A., Dewhirst M. W., Chilkoti A.: Drug targeting using thermally responsive polymers and local hyperthermia. Journal of Controlled Release, 74, 213-224 (2001). https://doi.org/10.1016/S0168-3659(01)00319-4

[43] Murthy N., Campbell J., Fausto N., Hoffman A. S., Stayton P. S.: Design and synthesis of $\mathrm{pH}$-responsive polymeric carriers that target uptake and enhance the intracellular delivery of oligonucleotides. Journal of Controlled Release, 89, 365-374 (2003). https://doi.org/10.1016/S0168-3659(03)00099-3 
[44] Murthy N., Robichaud J. R., Tirrell D. A., Stayton P. S., Hoffman A. S.: The design and synthesis of polymers for eukaryotic membrane disruption. Journal of Controlled Release, 61, 137-143 (1999).

https://doi.org/10.1016/S0168-3659(99)00114-5

[45] Kalyanasundaram K., Thomas J. K.: Environmental effects on vibronic band intensities in pyrene monomer fluorescence and their application in studies of micellar systems. Journal of the American Chemical Society, 99, 2039-2044 (1977).

https://doi.org/10.1021/JA00449A004

[46] Ringsdorf H., Venzmer J., Winnik F. M.: Fluorescence studies of hydrophobically modified poly( $N$-isopropylacrylamides). Macromolecules, 24, 1678-1686 (1991). https://doi.org/10.1021/MA00007A034
[47] Fahmy K., Merroun M., Pollmann K., Raff J., Savchuk O., Hennig C., Selenska-Pobell S.: Secondary structure and $\mathrm{Pd}(\mathrm{II})$ coordination in S-Layer proteins from bacillus sphaericus studied by infrared and X-ray absorption spectroscopy. Biophysical Journal, 91, 996-1007 (2006).

https://doi.org/10.1529/biophysj.105.079137

[48] Shirbin S. J., Ladewig K., Fu Q., Klimak M., Zhang Q., Duan W., Qiao G. G.: Cisplatin-induced formation of biocompatible and biodegradable polypeptide-based vesicles for targeted anticancer drug delivery. Biomacromolecules, 16, 2463-2474 (2015).

https://doi.org/10.1021/ACS.BIOMAC.5B00692

[49] Haxton K. J., Burt H. M.: Hyperbranched polymers for controlled release of cisplatin. Dalton Transactions, 2008, 5872-5875 (2008).

https://doi.org/10.1039/B809949A 